\title{
NATIONAL IDENTITY AND MARKET FREEDOMS AFTER THE TREATY OF LISBON
}

\begin{abstract}
Siniša Rodin*
Summary: The aim of this paper is to explore the balance between market freedoms and national regulatory autonomy following the entry into force of the Treaty of Lisbon, particularly in the light of the rephrased national identity guarantee under Article 4(2) TEU. The paper will discuss whether the newly established obligation of the European Union to respect the national identities of its Member States has any consequences in the case law of the European Court of Justice. Arguably, defining the proper scope of application of the national identity guarantee is relevant to the application of EU law, since it disturbs the previously established balance between European and national law. If defined too broadly, it can undermine the uniform application and effectiveness of EU law. If defined too narrowly, it would be devoid of any useful effect.
\end{abstract}

With this objective in mind, I will first clarify the concept of national identity and, more specifically, national constitutional identity. Second, I will discuss the case law of the ECJ preceding the entry into force of the Treaty of Lisbon. In this part, I will suggest that the development of national identity law before the Treaty of Lisbon went through three evolutionary phases: a phase of early and implicit national identity law; a phase in which the ECJ developed the margin of discretion doctrine; and a phase in which the ECJ started to differentiate national constitutional rules and accord them different levels of scrutiny. In the third part, I will explore whether there have been significant developments in the national identity case law of the ECJ after the entry into force of the Treaty of Lisbon, and suggest that the general approach of the ECJ has not significantly changed. I will also argue that the main developments related to Article 4(2) TEU have not taken place before the ECJ, but in national arenas, notably in France and Germany. In the fourth and final part, I will return to the issue of the differentiation of national identity claims and conclude that one category is understood by the ECJ as an ordinary justification of national measures restricting one of the market freedoms, while the other category of claims prompts the ECJ to defer to national authorities.

University of Zagreb, Faculty of Law. 


\section{Introduction}

The aim of this paper is to explore the balance between market freedoms and national regulatory autonomy following the entry into force of the Treaty of Lisbon, particularly in the light of the rephrased national identity guarantee under Article 4(2) TEU. The paper will discuss whether the newly established obligation of the European Union to respect the national identities of its Member States has any consequences in the case law of the European Court of Justice. Arguably, defining the proper scope of application of the national identity guarantee is relevant to the application of EU law, since it disturbs the previously established balance between European and national law. If defined too broadly, it can undermine the uniform application and effectiveness of EU law. If defined too narrowly, it would be devoid of any useful effect.

With this objective in mind, I will first clarify the concept of national identity and, more specifically, national constitutional identity. Second, I will discuss the case law of the ECJ preceding the entry into force of the Treaty of Lisbon. In this part, I will suggest that the development of national identity law before the Treaty of Lisbon went through three evolutionary phases: a phase of early and implicit national identity law; a phase in which the ECJ developed the margin of discretion doctrine; and a phase in which the ECJ started to differentiate national constitutional rules and accord them different levels of scrutiny. In the third part, I will explore whether there have been significant developments in the national identity case law of the ECJ after the entry into force of the Treaty of Lisbon, and suggest that the general approach of the ECJ has not significantly changed. I will also argue that the main developments related to Article 4(2) TEU have not taken place before the ECJ, but in national arenas, notably in France and Germany. In the fourth and final part, I will return to the issue of the differentiation of national identity claims and conclude that one category is understood by the ECJ as an ordinary justification of national measures restricting one of the market freedoms, while the other category of claims prompts the ECJ to defer to national authorities.

\section{Defining national identity}

As noted by Advocate General Maduro, national identity has been part of EU law from the beginning. ${ }^{1}$ It has been present in the Treaties since the adoption of the Treaty of Maastricht, where it was introduced in Article $\mathrm{F}(1)$ of the TEU, which states that 'The Union shall respect the

Case C-213/07 Michaniki AEv Ethniko Symvoulio Radiotileorasis and Ypourgos Epikrateias [2008] ECR I-9999, Opinion of AG Maduro, para 31. 
national identities of its Member States, whose systems of government are based on the principles of democracy'. The Article was subsequently renumbered and rephrased to become Article 6(3) of the Treaty of Amsterdam. The Amsterdam provision simply provided that 'The Union shall respect the national identities of its Member States.' Article I-5 of the Treaty establishing a Constitution for Europe rephrased the provision, the identical wording of which subsequently became paragraph (2) of Article 4 of the TEU.

According to Article 4(2) of the TEU:

[t]he Union shall respect the equality of Member States before the Treaties as well as their national identities, inherent in their fundamental structures, political and constitutional, inclusive of regional and local self-government. It shall respect their essential State functions, including ensuring the territorial integrity of the State, maintaining law and order and safeguarding national security. In particular, national security remains the sole responsibility of each Member State.

When compared to earlier statements, Article 4(2) speaks about 'fundamental structures, political and constitutional, inclusive of regional and local self-government', while the earlier text generally referred to national identities. It would seem that an added value of the new wording, which is ascribed to the chairman of Working Group V of the European Convention, Mr Henning Christophersen, is the explicit reference to national constitutional identity, whatever this may be. ${ }^{2}$ In a way, it was the semantic force of Article I-5 of the Constitutional Treaty that narrowed the discourse on national identity into discourse about national constitutional identity. The Treaty of Lisbon followed suit.

The Merriam-Webster dictionary defines identity as 'sameness in all that constitutes the objective reality of a thing' and 'the condition of being the same with something described or asserted'. In brief, identity can be described as a state of being the same as one thing and, at the same time,

2 The European Convention, which prepared the text of the Constitutional Treaty, discussed a number of proposals as to what should be explicitly mentioned as a part of national identity. Among the proposals, there were: 'constitutional and political structures including regional and local self-government and the legal status of churches and religious bodies' (Altmeier) and also 'language, national citizenship, military service, the educational systems, the welfare systems, including the public health systems, the system for personal taxation, the right of abortion'. See European Convention, Secretariat, Working Group V, Working Document 28, paper of the Chairman Mr Henning Christophersen on priority issues regarding complementary competence (circulated at the last meeting of WG V on 6 September 2002), Brussels 24 September 2002. Von Bogdandy and Schill name the clause, after the chairman of the Working Group, the Christophersen Clause. A von Bogdandy and S Schill, 'Overcoming Absolute Primacy: Respect for National Identity under the Lisbon Treaty’ 48 CML Rev (2011) 1417. 
differentiated from everything else. The word 'national' refers to nation Member States of the European Union. The words 'shall respect' and 'inherent in their fundamental structures' imply a normative claim that in certain essential areas of regulation, defined as 'fundamental structures, political and constitutional', the regulatory powers of the Member States should enjoy immunity from the encroachment of EU law.

Taken together, the wording of Article 4(2) TEU would appear to protect the right of the Member States and their citizens ${ }^{3}$ to define, independently of EU law, such elements of their constitutional and political order which make them unique and at the same time different from any other Member State or, indeed, from the European Union at large. Such essential elements constitute the specific content of what is referred to as national constitutional identity. In a certain sense, from the Lisbon Treaty onwards, national identity as a technical term under Article 4(2) TEU largely coincides with national constitutional identity. Therefore, I shall use the two terms interchangeably.

\subsection{Article 4(2) TEU identity and Article 2 TEU values}

One part of the national identity of the Member States is construed in terms of the rest of the World. Namely, by being a Member State of the $\mathrm{EU}$, a State is differentiated from all non-EU states. ${ }^{4}$ Membership of the $\mathrm{EU}$ forms an inextricable part of the Member States' identity. ${ }^{5}$ In normative terms, acceptance of certain EU-specific values contributes to what makes the national identities of the Member States unique. As a result of membership of the EU, the national identities of the Member States are understood to comprise the values of Article $2 \mathrm{TEU}$ on which the EU is founded, in particular:

values of respect for human dignity, freedom, democracy, equality, the rule of law and respect for human rights, including the rights of persons belonging to minorities ... in a society in which pluralism, non-discrimination, tolerance, justice, solidarity and equality between women and men prevail.

\footnotetext{
3 Von Bogdandy and Schill distinguish between an objective and subjective understanding of national identity, the former being based on objectively discernible criteria, such as a common language, history or political institutions, and the latter being defined by the 'will of individuals to belong to a community'. Von Bogdandy and Schill (n 2) 1430. The case law of the ECJ based on Article 4(2) TEU and its earlier forms appears to protect objective national identity as defined by national law and national institutions. If the interpretation were stretched to include the subjective element, the individual choice of belonging to a certain national identity would amount to an enforceable right under EU law.

4 For the importance of otherness in the construction of identity, see eg W Sadurski, 'European Constitutional Identity?' EUI Working Papers, LAW No 2006/33, 7-8.

5 Von Bogdandy and Schill (n 2) 1426.
} 
Respect for these values is a minimum requirement for EU membership. Once a State accepts these values by joining the EU, this becomes a rebuttable presumption that can be rebutted only subject to the procedure laid down by Article 7 TEU.

It can be said that Article 2 TEU defines those elements of national identity that are, at the same time, postulated by membership of the European Union and without which neither the Member States nor the European Union itself can claim legitimacy.

However, the concept of national identity is broader than the values enshrined in Article 2 TEU. Namely, the elements of national identity (constitutional identity included), such as Member States' fundamental political and constitutional structures, law and order, or national security, are construed independently at the national level. In other words, national identity and European values do not necessarily overlap. Nevertheless, it is a normative requirement of EU membership that even such elements of national identity which are constructed independently and regardless of the EU context, still have to comply with the values of Article 2 TEU. The history of the $20^{\text {th }}$ century teaches us that in the absence of this requirement, national 'fundamental structures, political and constitutional' would be capable of pursuing a variety of morally problematic ends.

That being said, one can conclude that not any kind of national identity would be tolerated within EU membership, but only the kind that promotes the values on which the Union is founded or which is at least neutral in respect of them.

In other words, the constitutional framework of the EU distinguishes between explicit 'good' and implied and dormant 'bad' national identities, the former being worthy of protection and the latter not. ${ }^{6}$ This was, after all, implicit in Article $\mathrm{F}(1)$ of the Maastricht Treaty, which linked respect for national identity to respect for the principles of democracy on the part of the Member States.

Figure 1 - overlapping identities

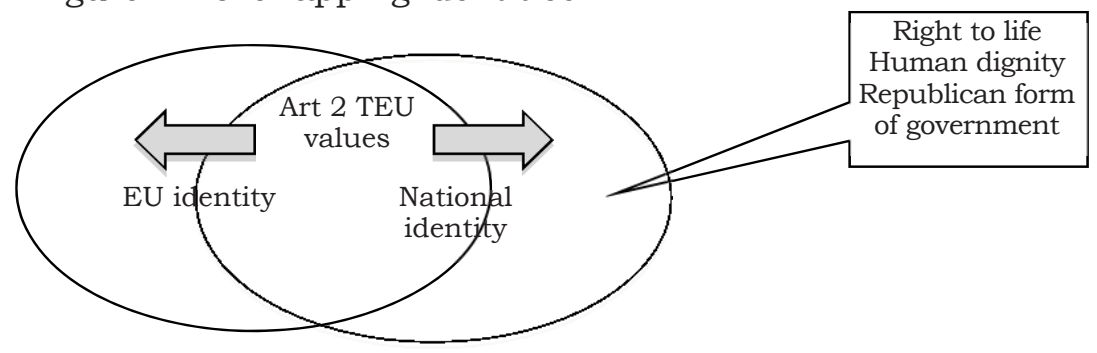

6 Arguably, a national constitutional provision reserving the right to vote to men would not be protected by Article 4(2) TEU, since it contradicts the value of equality under Article 2 TEU. 


\subsection{National identity and other Treaty values}

A separate set of values, applicable to all areas of EU regulation, is laid down in Part I, Title II, Articles 9 and 10 of the TFEU. These provisions enshrine values that have to be respected in defining and implementing EU policies. They include a high level of employment, guaranteeing adequate social protection, fighting against social exclusion, providing a high level of education and training, protecting human health, and fighting against discrimination based on sex, racial or ethnic origin, religion or belief, disability, age or sexual orientation. The function of these provisions is anything but clear. The values enshrined therein may create restraints for supranational policy-making. Most of them have been granted constitutional protection at the national level and arguably may constitute part of national constitutional identity. The question, however, is whether reliance on Articles 9 and 10 TFEU may broaden the regulatory discretion of the Member States and change the balance between EU and national law.

Advocate General Cruz Villalon argued in his Opinion in Palhota that the ECJ should recognise broader discretion for the Member States in the pursuit of the values listed in Article 9 of the TFEU, such as a high level of employment, the guarantee of adequate social protection, the fight against social exclusion, and a high level of education, training and protection of human health. Accordingly, mandatory requirements justifying a departure from market freedoms should no longer be interpreted narrowly. For example, the social protection of workers should be taken into account in the performance of a proportionality test when assessing whether national measures restricting the free movement of services are justified. The result of such reasoning would be that a Member State is allowed to maintain its own understanding of social policy, for example providing adequate social protection in such a way that it could narrow the scope of application of, for example, the free movement of workers. This is essentially no different from claiming that a high level of social protection constitutes part of the national identity of certain Member States and justifies a departure from market freedoms.

In Palhota, the issue was raised whether a national measure requiring an employer, established in one Member State and posting workers to the territory of another, to send a prior declaration of posting can be justified in the context of the free movement of services. After having presented its proportionality analysis in paragraph 49, the ECJ went on to assess the appropriateness and necessity of the national measure. The ECJ found that there is a less restrictive measure for the employer, namely, 'to report beforehand to the local authorities on the presence of one

See Case C-515/08 Palhota, Opinion of AG Cruz Villalon, paras 51-53, not yet reported. 
or more deployed workers, the anticipated duration of their presence and the provision or provisions of services justifying the deployment'. ${ }^{8}$

While the Advocate General's suggestion may have provided discretion to the Member State to choose from among equally effective measures, and select one which serves the protection of workers better, the ECJ maintained the traditional test of the least restrictive alternative for the free movement of services.

Palhota is the first and only ${ }^{9}$ post-Lisbon case so far where the existing free-movement case law was challenged by an Advocate General and survived. Accordingly, a fully developed proportionality test remains applicable to situations where Member States invoke the mandatory requirements mentioned in Articles 9 and 10 TFEU. After the entry into force of the Treaty of Lisbon, the ECJ has even strengthened the level of scrutiny by requiring national legislation allegedly promoting a high level of protection of human health to be applied in a consistent and systematic manner. ${ }^{10}$

\subsection{National identity and regulatory competence}

EU law restricts regulatory autonomy of the Member States in both the area of Union and Member State competence. The same holds for the national identity guarantee under Article 4(2) TEU.

First, as a part of Article 4 TEU, the national identity guarantee represents part of a more general system of co-operation between the Union and the Member States. Upon closer examination, Article 4 TEU lays down several different guarantees that have to be understood in the context of Article 5 TEU.

The first paragraph of Article 4 TEU is a competence rule. ${ }^{11}$ It stipulates the residual powers of the Member States, and in this way complements the principle of conferral laid down by Article 5(1) TEU. The Union is based on the principle of conferred powers, the residue of which rests with the Member States. In this light, it is perfectly clear that, as a matter of competence, the national identity guarantee refers but, as I will shortly

\footnotetext{
$8 \quad$ Palhota (n 7) para 51.

9 A similar suggestion that national courts should be granted more discretion was introduced by AG Cruz Villalon and ignored by the ECJ in a procedural context. See Case C-173/09 Georgi Ivanov Elchinov v Natsionalna zdravnoosiguritelna kasa, not yet reported.

10 Joined Cases C-570/07 and C-571/07 José Manuel Blanco Pérez and María del Pilar Chao Gómez v Consejería de Salud y Servicios Sanitarios (C-570/07) and Principado de Asturias (C-571/O7), para 94, not yet reported. For an analysis of consistency and coherence in the case law, see G Mathisen, 'Consistency and Coherence as Conditions for Justification of Member State Measures Restricting Free Movement', 47 CML Rev (2010) 1021.

11 Art 4(1) TEU: 'In accordance with Article 5, competences not conferred upon the Union in the Treaties remain with the Member States.'
} 
show, is not limited to the powers conferred on the EU. In its regulatory dimension, Article 4(2) TEU can be understood as a rule that delimits the exercise of the powers conferred. In other words, it can be interpreted as prohibiting the Union from acting even in areas where regulatory competences have been conferred, if the exercise of such competences would affect Member States' national identity. Arguably, the same would hold even in situations where the exercise of EU competence would 'genuinely have as its object the improvement of the conditions for the establishment and functioning of the internal market' within the meaning of paragraph 84 of the Tobacco Advertising case. ${ }^{12}$

Furthermore, if national identity is to be distinguished from the principles of subsidiarity and proportionality enshrined in Article 5(3) and (4) TEU, then it cannot come under national parliaments' scrutiny under the Protocol on the application of the principles of subsidiarity and proportionality. A plausible interpretation would be that the national identity guarantee should be applicable even in cases where an act of the EU has already passed the national parliaments' muster, ie despite it being in compliance with the principle of subsidiarity.

Alternatively, it could be argued that since national identity construction pertains to the Member States, it represents an inherent part of the subsidiarity principle. A consequence of this approach would be that once national parliaments have not objected to the adoption of a rule on subsidiarity grounds, it is presumed that the rule in question respects national constitutional identity. There is no support for either interpretation in the parliamentary practice of the Member States so far.

Secondly, Article 4(2) TEU also plays a role in the area of Member State exclusive competence. While one could expect that in this area the national identity guarantee is uncontested by the very nature of exclusive competence, it is not the case. Namely, it is well established in the case law of the ECJ that even in areas where the Member States have exclusive competence, such as when regulating civil status ${ }^{13}$ or higher

12 Case C-376/98 Federal Republic of Germany $v$ European Parliament and Council of the European Union [2000] ECR I-8419.

13 Case C-267/06 Tadao Maruko v Versorgungsanstalt der deutschen Bühnen [2007] ECR I-1757, para 55: 'civil status and the benefits flowing therefrom are matters which fall within the competence of the Member States and Community law does not detract from that competence. However, it must be recalled that in the exercise of that competence the Member States must comply with Community law and, in particular, with the provisions relating to the principle of non-discrimination.' See also Case C-372/04 Watts [2006] ECR I-4325, para 92; Case C-444/05 Stamatelaki [2007] ECR I-3185, para 23; Case 120/78 Rewe-Zentral AG v Bundesmonopolverwaltung für Branntwein [1979] ECR 649, para 8; Case C-76/05 Schwarz and Gootjes-Schwarz [2007] ECR I-6849, para 70; Joined Cases C-11/06 and C-12/06 Morgan and Bucher [2007] ECR I-9161, para 24; and most recently, in the context of higher education, Case C-73/08 Nicolas Bressol and Others and Céline Chaverot and Others v Gouvernement de la Communauté française [2010] ECR I-2735, para 28. 
education, ${ }^{14}$ their competence cannot be exercised against EU law. The most recent confirmation of this position can be found in Rottman, regarding the regulation of national citizenship. ${ }^{15}$ As I will demonstrate below, in Rottman, which both the referring court and the Advocate General understood as a national identity case, the ECJ acknowledged the regulatory competence of the Member State concerned, but nevertheless asserted its case law, according to which the Member States are bound by EU law even in areas of their competence. ${ }^{16}$ Thus, it becomes clear that Article 4(2) TEU is applicable in areas of Member State exclusive competence.

The obligation of the Member States to respect EU law is also present with regard to national procedural law, where it is conventionally understood that the Member States enjoy national procedural autonomy subject to respect for the principles of effectiveness and equivalence. However, as Bobek rightly points out, such national autonomy does not really exist, since even national procedural legislation is subject to the scrutiny of the ECJ. ${ }^{17}$ Clearly any claims that certain features of national procedural law represent part of national constitutional identity are equally doomed to failure, ${ }^{18}$ as was demonstrated in Elchinov. ${ }^{19}$

A number of cases that deal with national identity values have been located in the sphere of Member State competence, such as the right to life, human dignity, the nationality of teachers and notaries, republican government, the use of national languages, the civic status of citizens and, indeed, the regulation of national constitutional procedures. Since national identity claims will typically be emphasised more in areas of Member States' exclusive competence, it can be reasonably expected that fine-tuning between market freedoms and national identity claims will take place along the lines sketched by Roman Herzog and Lüder Gerken in their comment published in 2008 following the contentious Mangold $^{20}$

14 Bressol (n 13).

15 Case C-135/08 Janko Rottman v Freistaat Bayern [2010] ECR I-1449.

16 Rottman (n 15) para 41: "Nevertheless, the fact that a matter falls within the competence of the Member States does not alter the fact that, in situations covered by European Union law, the national rules concerned must have due regard to the latter'; and para 45: 'Thus, the Member States must, when exercising their powers in the sphere of nationality, have due regard to European Union law'. See also the case law cited therein.

17 M Bobek, 'Why there is no Principle Of "Procedural Autonomy" of the Member States', forthcoming in B de Witte and H Micklitz (eds), The European Court of Justice and the Autonomy of the Member States (Intersentia 2011).

18 However, the ECJ is prepared to allow an implicit margin of discretion. For a recent example, see Case C-291/09 Francesco Guarnieri \& Cie (not yet reported), where the ECJ took the position that a national rule is 'purely procedural and its purpose is not to regulate trade in goods.' See para 16. Accordingly, the impact of the national procedural rule was 'too uncertain and indirect.'

19 Elchinov (n 9).

20 Case C-144/04 Werner Mangold v Rüdiger Helm [2005] ECR I-9981. 
judgment of the ECJ. ${ }^{21}$ The tension can be summarised as follows: either the ECJ will start to exercise self-restraint, or national constitutional courts will have to take the protection of national constitutional identity more seriously.

\section{National identity before the Treaty of Lisbon}

Roughly speaking, national identity jurisprudence before the Treaty of Lisbon went through three evolutionary phases. In the first phase, national identity was not claimed as such, but was recognised in an implicit way by means of national insistence on constitutional standards for the protection of fundamental rights. The second phase followed in the early ' 90 s and was characterised by the development of a margin of discretion. The third pre-Lisbon phase resulted in the concession that national constitutional identity is not absolute. This third phase heralded a subsequent differentiation of national constitutional rules into two classes: fundamental constitutional provisions 'worthy' of deferring to national authorities and other constitutional provisions treated like ordinary justifications.

\subsection{The 'old' national identity law}

Judicial reference to national constitutional identity is well discussed in legal scholarship. Two well-known references are the early Solange dialogue between the German Federal Constitutional Court and the ECJ, ${ }^{22}$ and the Frontini judgment of the Italian Constitutional Court establishing the theory of countervailing power to the supranational transfer of sovereignty, ie so-called controlimiti. ${ }^{23}$ According to the Frontini reservation, the transfer of sovereignty, which is inherent in the Founding Treaties, cannot include the transfer of powers to Community institutions to violate the fundamental principles of the Constitution or the inalienable rights of man.'

German and Italian reactions were prompted by the evolving doctrine of supremacy, which after its inception in Costa $v E N E L^{24}$ was crystalli-

\footnotetext{
21 R Herzog and L Gerken, 'Stop the European Court of Justice', Zentrum für Europäische Politik, Freiburg 2008. Published originally in Frankfurter Algemeine Zeitung (8 September 2008). See also EUobserver, 11 September <http://euobserver.com/9/26714> accessed 8 August 2011. The core argument is as follows: 'both labor market policy and social policy are still core competences of the Member States. However, this case clearly demonstrates to what extent EU regulation and EU jurisdiction nevertheless interfere in the governing of these core competences.'

22 Solange I, BVerfGE 37, 271; Solange II, BVerfGE 73, 339; Maastricht, BVerfGE 89, 155.

${ }^{23}$ Italian Constitutional Court Case no 183/73 Frontini $v$ Ministero delle Finanze in A Oppenheimer (ed), The Relationship between European Community Law and National Law: The Cases (CUP 2005); M Cartabia, 'Nuovi sviluppi nelle "competenze comunitarie" della Corte costituzionale, nota a sentenza n. 232 del 1989', in Giurisprudenza costituzionale 1989, 1012. 24 BVerfGE 37, 271, 2 BvL 52/71.
} 
sed by the ECJ in the Internationale Handelsgesellschaft case where the Court boldly observed that:

the validity of a Community measure or its effect within a Member State cannot be affected by allegations that it runs counter to either fundamental rights as formulated by the constitution of that State or the principles of a national constitutional structure. ${ }^{25}$

The ECJ followed the same line of reasoning in its subsequent case law. For example, in the Belgian Flemish Government case, ${ }^{26}$ the Flemish government attempted to justify discrimination on the grounds of a lack of regulatory competence in the matter, which according to the Belgian constitution belongs to the federal government. The ECJ shunned the argument by reiterating its earlier case law, stating that 'a Member State cannot plead provisions, practices or situations prevailing in its domestic legal order, including those resulting from the constitutional organisation of that State, to justify the failure to observe obligations arising under Community law'. ${ }^{27}$

Advocate General Sharpston rightly pointed to Article 27 of the 1969 Vienna Convention on the Law of Treaties, according to which '[a] party may not invoke the provisions of its internal law as justification for its failure to perform a treaty. ${ }^{28}$ It is now widely accepted that the Vienna Convention also refers to national constitutional law. ${ }^{29}$ Nevertheless, German insistence on high standards of protection of fundamental rights

${ }_{25}$ Case 11/70 Internationale Handelsgesellschaft mbH $v$ Einfuhr- und Vorratsstelle für Getreide und Futtermittel [1970] ECR 1125.

26 Case C-212/06 Government of Communauté française and Gouvernement wallon $v$ Gouvernement flamand [2008] ECR I-1683.

27 Government of Communauté française and Gouvernement wallon (n 26) para 58. See also Case C-87/02 Commission v Italy [2004] ECR I-5975, para 38; Case 69/81 Commission $v$ Belgium [1982] ECR 163, para 5; Case C-323/96 Commission v Belgium [1998] ECR I-5063, para 42; Case C-236/99 Commission v Belgium [2000] ECR I-5657, para 23; Case C-111/00 Commission v Austria [2001] ECR I-7555, para 12.

28 See Government of Communauté française and Gouvernement wallon (n 26), Opinion of AG Sharpston fn 57.

29 Concerning national constitutional law, André de Hoogh draws attention to the drafting history of Article 27 of the Vienna Convention which 'confirms that the reference to internal law comprises the constitution of a State party. In fact, the amendment proposed by Pakistan initially claimed "[e]very treaty in force is binding upon the parties to it and must be performed by them in good faith, and no party may invoke the provisions of its constitution or its laws as an excuse for its failure to perform this duty" (Vienna Conference, Documents, p 145; adopted: 55 in favor, none against, 30 abstentions (Vienna Conference, First Session, $p$ 158)). Though certain hesitations may be observed on the part of the participants in the Vienna Conference in 1968-1969 to support the resulting provision (adopted: 73 in favour, 2 against, 24 abstentions; Vienna Conference, Second Session, p 54), as to this particular point, the provision did find favor and only two States (Venezuela and Iran) expressed their opposition suggesting the primacy of their constitutional law over treaties. Two States (Venezuela and Guatemala) specifically attached reservations on this point, against which objections have been raised by certain other States', A de Hoogh, 'The Relationship between National Law and International Law in the Report of the Georgia Fact-Finding Mission' (EJIL: Talk!) <www.ejiltalk.org> accessed 15 July 2011. 
prompted the development of significant fundamental rights case law and ultimately to the adoption of the Charter of Fundamental Rights of the EU.

\subsection{Second phase: margin of discretion}

Margin of discretion is the power exercised by the Member States in areas of regulation falling within the scope of EU law. In such areas, Member States can justify derogations from EU law by demonstrating a broadly defined legitimate regulatory aim..$^{30}$ To justify the aim as legitimate, a Member State can rely on a variety of self-defined interests that need not be shared by other Member States. However, such interests must not run against the values of EU law and must pass the proportionality test. Margin of discretion started to play a more significant role in the early 1990s following the judgment of the ECJ in SPUC $v$ Grogan. ${ }^{31}$

For the purpose of the present discussion, it is useful to distinguish between two different types of discretion.

The first type is the discretion that Member States exercise in the implementation of EU law, notably, directives. Such discretion may pertain to the legislative authorities ${ }^{32}$ or to the national courts when interpreting national law. ${ }^{33}$ The Van Duyn situation, where national public authorities had to interpret public policy justification, also falls within this type. This first type of discretion does not give the Member States a licence to depart from compliance with EU law but, on the contrary, discretion to interpret national law in line with EU law. ${ }^{34}$

The second type of discretion is of constitutional significance and concerns potentially competing national and European values. In a case where a European and national rule or value do not coincide, one of the two has to give way to the other. In such situations, both the EU and Member State have normative claims that the European or national

\footnotetext{
30 In areas that fall outside the scope of EU law, one cannot speak about discretion, but Member States are still under an obligation to 'have a due regard to EU law'. In Hohfeldian terms, one could say that Member States enjoy immunity from application of EU law in areas where the EU has exercised its regulatory competence. WN Hohfeld, 'Fundamental Legal Conceptions as Applied in Judicial Reasoning' 26 Yale LJ (1916-1917) 710, 711.

31 Case C-159/90 The Society for the Protection of Unborn Children Ireland Ltd $v$ Stephen Grogan and others [1991] ECR 4685.

32 See eg Joined Cases C-482/01 and C-493/01 Georgios Orfanopoulos and Others and Raffaele Oliveri v Land Baden-Württemberg [2004] ECR 5257, para 114; Case C-271/91 Marshall [1993] ECR I-4367, para 37; Joined Cases C-397/01 to C-403/01 Bernhard Pfeiffer and others [2004] ECR I-8835, para 105.

33 Case C-208/05 ITC Innovative Technology Center GmbH v Bundesagentur für Arbeit [2007] ECR I-181, paras 68 and 69. The ECJ allowed the discretion of the national court to be used to interpret national law in line with EU law.

${ }^{34}$ Case 41/74 Yvonne van Duyn v Home Office [1974] ECR 1337, para 18. See also 30/77, Régina v Pierre Bouchereau [1977] ECR 1999, para 34.
} 
rule or value should control the other. When the two rules or values are allowed to co-exist without an imminent resolution, one can speak about either an implied or an explicit margin of discretion.

The ECJ has so far recognised margin of discretion in explicit and implied ways. Examples of an explicit margin of discretion are Schmidberger ${ }^{35}$ and Omega. ${ }^{36}$ Implicitly, the ECJ granted a margin of discretion in SPUC $v$ Grogan and Melki and Abdeli. ${ }^{37}$

Implied margin of discretion is best illustrated in SPUC $v$ Grogan, ${ }^{38}$ where the ECJ had to address the tension between a national constitutional rule defining the right to life and the free movement of services. As is commonly known, the tension was resolved on jurisdictional grounds and Community law was found to be inapplicable.

The significance of SPUC $v$ Grogan is in highlighting the fact that national constitutional values may escape the scrutiny of EU law, as long as they are outside its scope. Nevertheless, soon after the case had been decided, Ireland was able to introduce a specific protocol to the Maastricht Treaty, which granted immunity and according to which nothing in the Treaty on European Union, or in the Treaties establishing the European Communities, or in the Treaties or Acts modifying or supplementing those Treaties, shall affect the application in Ireland of Article 40.3.3 of the Constitution of Ireland'. ${ }^{39}$

The Protocol amounts to a constitutional amendment, the purpose of which was to prevent the Grogan situation from re-emerging in an economic context and not being resolved by functional reasoning.

Indeed, jurisdictional rules may relieve the ECJ from passing its judgment on highly sensitive national constitutional choices, such as the prohibition of the public display of communist symbols in the Attila Vajnai case. ${ }^{40}$ While it is easy to agree that the prohibition of the red star represents part of Hungarian post-communist identity, constructed against negative historical experiences, the non-economic nature of the activity put the case outside the scope of EU law.

Implied margin of discretion is, as one can see, of a jurisdictional nature, and the ECJ controls it through functional concepts such as economic activity, undertaking, official authority or internal situation.

\footnotetext{
35 Case C-112/00 Eugen Schmidberger, Internationale Transporte und Planzüge v Republik Österreich [2003] ECR I-5659.

36 Case C-36/02 Omega Spielhallen- und Automatenaufstellungs-GmbH v Oberbürgermeisterin der Bundesstadt Bonn [2004] ECR I-9609.

37 Joined Cases C-188/10 and C-189/10 Aziz Melki and Sélim Abdeli, not yet reported.

38 SPUC $v$ Grogan (n 31).

39 Protocol annexed to the Treaty on European Union and to the Treaties establishing the European Communities.

40 Case C-328/04 Criminal proceedings against Attila Vajnai [2005] ECR I-8577.
} 
A more complicated situation arises when a conflict cannot be avoided by jurisdictional means. In such situations, one value has to prevail over the other. The ECJ has already dealt with such situations in Schmidberger, Omega and Küçükdeveçı. ${ }^{41}$ In all such situations, the following general rule applies: once a case is brought within the scope of EU law, either by direct application of a Treaty rule or by a directive, a rule or general principle of EU law can have exclusionary effects. This is also an instance where the concept of national identity can have an impact and possibly restrict the exclusionary effects of EU law. Hic Rhodus, hic salta!

The three mentioned cases are, however, different as to the nature of the protected national values. In Schmidberger, it was freedom of assembly as a fundamental right, in Omega it was human dignity as a fundamental constitutional value, while in Küçükdeveçı it was an instrument of social policy. ${ }^{42}$ Moreover, while freedom of assembly is a value endorsed by the EU and all the Member States, human dignity, was, before the entry into force of the Charter of Rights of the EU, ${ }^{43}$ a specific characteristic of the German constitutional order that was compatible with EU values ${ }^{44}$ but not necessarily recognised at the constitutional level by other Member States. The case is similar to social policy measures, where the Member States, by the very nature of the area and Treaty-entrenched choice, exercise wide discretion. Do these differences have any significance in respect of the breadth of the margin of discretion?

In all three cases, the ECJ insisted on the legitimate aim of national regulation. ${ }^{45}$ As long as that aim is juxtaposed with a market freedom, it is legitimate, as it is compatible with the broader referential framework (general principles) of EU law. In two out of the three mentioned cases, this was the case, as national measures were found to be compatible or, at least, reconcilable with general principles of EU law. ${ }^{46}$ In Küçükdeveçi, the national measure was found to be in accordance with the social policy justifications provided for by Directive $2000 / 78,{ }^{47}$ but not in accordance with a broader referential rule: the general principle of non-discrimination. In other words, there was no compatibility between national law and EU law at the level of the broader referential framework of the EU, and so the national law had to be set aside.

\footnotetext{
${ }^{41}$ Case C-555/07 Seda Küçükdeveçi v Swedex GmbH \& Co KG [2010] ECR I-365.

42 Küçükdeveçi (n 41) para 36.

43 The Charter guarantees human dignity in Article 1.

44 Omega (n 36) para 34.

45 Schmidberger (n 35) paras 79 and 80; Küçükdeveçi (n 41) para 36; Omega (n 36) para 35.

46 Schmidberger (n 35) paras 71-73; Omega (n 36) para 34.

47 Küçükdeveçi (n 41) para 36. See Article 6(1) of Council Directive 2000/78/EC of 27 November 2000 establishing a general framework for equal treatment in employment and occupation, OJ L 303, 2 December.2000, 16-22.
} 
If Article 4(2) TEU has an effect, it should be tested in situations where an element of national identity does not coincide with the broader referential value framework of the EU. Neither Schmidberger nor Omega is such a case, bearing in mind that the protection of fundamental rights is an important element of identity of both the EU and its Member States.

Nor is Küçükdeveçı, though for different reasons. Policy, including social policy, is a variable of national government. It is at the discretion of the executive branch to formulate and implement various policies, and for that reason there can be no equation between policy and national constitutional identity. EU law does not prescribe any given direction in which Member States should frame their social policy and does not interfere with Member States' choice to constitute themselves as a welfare state. A genuine conflict between EU law and national constitutional identity would emerge only if EU law touched upon the fundamental constitutional choice of a Member State, for example, to constitute itself within a certain socio-economic or political framework. ${ }^{48}$

To conclude, the second period in which the national identity guarantee was framed did not bring about a meaningful definition of national identity or consequently a resolution of the tension between national identity and internal market freedoms.

\subsection{Third phase: differentiation of constitutional rules}

It was only after the signing of the failed Constitutional Treaty that the national identity guarantee was linked directly not to a vague concept of national identity but to a somewhat more concrete concept of constitutional identity. It was only after the entry into force of the Treaty of Lisbon that this linkage obtained legal significance.

Parallel with Treaty incorporation, an awareness emerged that not every national constitutional claim automatically represents a constituent part of national constitutional identity. While AG Maduro suggested in Michaniki that a contested rule of the Greek constitution should be understood as an element of national identity, ${ }^{49}$ the ECJ simply assessed the contested rule according to the usual proportionality test. ${ }^{50}$ Its legitimacy depended on the extent it pursued the interests of transparency and equal treatment, which at the same time are principles defined by EU law.

The approach of the ECJ in Michaniki led Besselink to suggest that:

\footnotetext{
48 Arguably, such a conflict would emerge if a Member State opted to abandon a market economy, which is a condition of EU membership.

49 Maduro (n 1) para 33.

50 See V Kosta, 'Case C-213/07 Michaniki AE v Ethniko Simvoulio Radiotileorasis, Ipourgos Epikratias' 5 Eur Const L Rev (2009) 501.
} 
more trivial provisions of national constitutional law - those which do not form part of the constitutional identity of the Member State - are not granted such priority [over EU law], and the normal Costa doctrine of the priority of directly effective EU law prevails. ${ }^{51}$

Von Bogdandy and Schill hold the same and suggest that 'only fundamental structures of the Member States are relevant.' ${ }^{22}$ If this interpretation is correct, then the function of Article 4(2) TEU would be to create a referential framework for the ECJ when making a distinction between essential and non-essential elements of national constitutions. The described approach would require different intensities of judicial scrutiny.

In the case of non-essential elements, the ECJ would perform a proportionality test under which a national identity claim would not be an automatic justification for departure from economic freedoms. Provided a regulatory aim is legitimate, a national measure will still need to be appropriate and necessary, regardless of whether it can be characterised as an element of national identity or not. ${ }^{53}$ Member States will enjoy a margin of discretion, however, only insofar as their measures can be reconciled with the broad referential framework of EU law. ${ }^{54}$ In cases where essential elements are concerned, the ECJ would defer the decision to the national judicial or legislative authorities, with (Omega) or without (SPUC $v$ Grogan) reserving a proportionality test for itself.

In support of such an interpretation is the fact that so far the ECJ has been more generous in granting a margin of appreciation in cases involving fundamental right guarantees and national constitutional values than in cases involving ordinary national law, even in cases of well-established national civil law principles..$^{55}$

AG Maduro himself implicitly recognised in paragraph 33 of his Opinion in Michaniki that some constitutional rules are capable of triggering

\footnotetext{
51 LFM Besselink, 'National and Constitutional Identity before and after Lisbon' 6 Utrecht L Rev 3 (2010) 36, 49.

52 Von Bogdandy and Schill (n 2) 1431.

53 Schmidberger (n 35) paras 82-87; Kücükdeveçi (n 41) para 37; Omega (n 36) para 36.

54 As far as margin of discretion is concerned, in Küçükdeveçı ((n 41) para 38), the ECJ restated its well-established position that Member States enjoy a wide margin of discretion in framing their respective social policies. In Schmidberger ((n 35) para 89), a broad margin was allowed to national authorities in striking a balance between a fundamental right and market freedom. In Omega ((n 36) para 31), again, the margin was decided as being broad. 55 In Traghetti del Mediterraneo, the ECJ ruled that EU law precluded the application of a national law which excludes state liability for damages for breach of EU law for damage caused to individuals by an infringement attributable to a court adjudicating in the last instance, or which restricts liability for damages arising from erroneous application of EU law by a national court to cases of intentional fault, serious misconduct and denial of justice. In such a case, the Simmenthal mandate is fully applicable and the national court has to set the national legal rule aside. Case C-173/03 Traghetti del Mediterraneo SpA v Repubblica Italiana [2006] ECR I-5177, para 46.
} 
the national identity guarantee under Article 4(2) TEU, while some are not. ${ }^{56}$ The same thought was introduced by AG Kokkot in UGT-Rioja, ${ }^{57}$ where she interpreted the ECJ's position concerning the balance between respect for national constitutional principles and observance of EU Law. ${ }^{58}$ According to AG Kokkot, while the ECJ respects local autonomy as defined by national constitutions, 'the Member States cannot hide behind their constitutional order and circumvent the prohibition on aid under Article 87 EC through a purely formal transfer of legislative powers'. ${ }^{59}$ Whether this was the case or not was left to the national court to decide. ${ }^{60}$

As far as the ECJ is concerned, as early as 1996, in Commission $v$ Luxembourg, ${ }^{61}$ the ECJ recognised national identity as a legitimate aim, though subject to the application of a proportionality test. ${ }^{62}$ Accordingly, a Member State may not invoke national identity in order to derogate from a market freedom as long as there is a less restrictive alternative to freedom of movement.

More recently, the ECJ supported the differentiation thesis in Rottman, decided in March 2010, ${ }^{63}$ where the referring court suggested that 'the effect of assuming that there existed, in European Union law, an obligation to refrain from withdrawing naturalisation obtained by deception would be to strike at the heart of the sovereign power of the Member States'. ${ }^{64}$

In his Opinion in Rottman, AG Maduro suggested that the power to deprive a person of Member State citizenship represents an 'essential element' of a Member State's national identity, since it affects the composition of the national body politic. Accordingly, making national citizenship dependent on EU citizenship would contravene Article 6(3) TEU (now 4(2) TEU). This, however, follows, not from the national identity provision alone, but from the very architecture of Union citizenship, which is explicitly

\footnotetext{
56 See paragraph 33 of the Opinion: 'It is, nevertheless, necessary to point out that that respect owed to the constitutional identity of the Member States cannot be understood as an absolute obligation to defer to all national constitutional rules.' The wording 'all national constitutional rules' implies that there may be some constitutional rules which automatically trigger deference.

57 Joined Cases C-428/06 to C-434/06 Unión General de Trabajadores de La Rioja (UGTRioja) and Others $v$ Juntas Generales del Territorio Histórico de Vizcaya and Others [2008] ECR I-6747, paras 56-57.

58 The Advocate General referred to Case C-88/03 Portuguese Republic $v$ Commission of the European Communities [2006] ECR I-7115.

59 Portuguese Republic $v$ Commission of the European Communities (n 58), Opinion of AG Kokkot, para 57.

60 UGT-Rioja (n 57) para 144.

61 Case C-473/93 Commission v Luxembourg [1996] ECR I-3207, para 35.

62 Commission v Luxembourg (n 61).

63 Rottman (n 15), Opinion of AG Maduro, para 25.

${ }^{64}$ Rottman (n 15) para 32.
} 
made secondary to national citizenship. Accordingly, the ECJ ignored the Advocate General's argument and decided the case on the grounds of the exclusionary effects of EU citizenship law. ${ }^{65}$

Even more recently, national identity was claimed as a derogation in the 'Notaries' Cases', decided in May 2011.66 The argument introduced by the Grand Duchy was that:

since the use of the Luxembourgish language is necessary in the performance of notarial activities, the nationality condition at issue is intended to ensure respect for the history, culture, tradition and national identity of Luxembourg within the meaning of Article 6(3) EU

(which was applicable at the material time). ${ }^{67}$ However, the ECJ was not impressed by the argument, and invoked its earlier position according to which national identity can be 'effectively safeguarded otherwise than by a general exclusion of nationals of the other Member States'. ${ }^{68}$ What is noteworthy is that the ECJ, in paragraph 124 of the judgment, spoke about Article 4(2) TEU of the Treaty of Lisbon, but relied on the reasoning expressed in its 2006 judgment, indicating that there was no substantial change between the Maastricht, Amsterdam and Lisbon positions.

On balance, national identity claims had limited success in the preLisbon era. On the one hand, Member States were successful in what can be called implied margin of discretion cases, where the ECJ refused to rule on national value choices on jurisdictional grounds. However, on the substantive count, justification on the grounds of national identity was argued a number of times in order to justify restriction of market freedoms but with limited success. When it comes to substantive conflicts, the ECJ treated national identity as a general justification and balanced it against market freedoms or other values of EU law.

\section{National identity and the Treaty of Lisbon}

As I have already mentioned in the introduction, the national identity provision was first introduced as part of Article I-5 of the Constitutional Treaty and was subsequently transposed into Article 4(2) of the TEU.

While the first Treaty defined the concept only in vague terms, Article I-5 of the Constitutional Treaty and the subsequent Article 4(2) TEU

\footnotetext{
65 Rottman (n 15) para 41. However the ECJ deferred the proportionality test to the national court.

66 Cases C-47/08, C-50/08, C-51/08, C-53/08, C-54/08, C-61/08 and C-52/08 Commission v Belgium, France, Luxembourg, Austria, Germany, Greece and Portugal, not yet reported.

${ }_{67}$ Commission v Luxembourg (n 61) para 72.

68 Commission v Luxembourg (n 61) para 124.
} 
added some clarity to the concept, defining it as national 'fundamental structures, political and constitutional'. Looking into the legislative history of the European Convention that originally framed the text of what has today become Article 4(2) TEU, Working Group V 'Complementary Competences', in its final report to the European Convention, ${ }^{69}$ emphasised that 'the provision was not a derogation clause' and that 'the Member States will remain under a duty to respect the provisions of the Treaties.' Instead, the Working Group explained that the purpose of the provision is 'that the Union, in the exercise of its competence, is under an obligation to respect the national identities of the Member States', which is subject to the interpretation of the ECJ, which is the "ultimate interpreter of the provision if the political institutions went beyond a reasonable margin of appreciation. ${ }^{70}$

In addition, the newly phrased Article 4(3) TEU has introduced a more balanced approach to the duty of loyal co-operation. According to the new wording, pursuant to the principle of sincere cooperation, the Union and the Member States shall, in full mutual respect, assist each other in carrying out tasks which flow from the Treaties'.

This is not quite the same as the former Article 10 TEC, according to which the addressees of the duty of loyal co-operation were only the Member States. A long line of cases based on Article 10 TEC fashioned the provision so as to create concrete obligations on the part of Member States, such as the obligation of EU-friendly interpretation ${ }^{71}$ or the obligation to make good damages for breach of EU law. ${ }^{72}$ Now, for the first time, the duty of co-operation has become reciprocal, that is, binding on the EU and on the Member States at the same time.

Reading paragraphs (2) and (3) of Article 4 TEU together, two questions arise. First, to what extent can these provisions, taken together, be interpreted as creating an enforceable obligation for the EU to interpret national law while taking into account national identity? Second, to what extent do they authorise the Member States to derogate from EU law on the grounds of national identity?

\subsection{European Court of Justice}

There are two recent cases referring to national identity which were decided after the entry into force of the Treaty of Lisbon: Sayn Wittgen-

69 CONV 375/02 REV1 WG V 14, Brussels, 4 November 2002.

70 CONV 375/02 REV1 WG V 14 (n 69) 11.

71 Case 14/83 Sabine von Colson and Elisabeth Kamann $v$ Land Nordrhein-Westfalen [1984] ECR 1891.

72 Joined Cases C-6/90 and C-9/90 Andrea Francovich and Danila Bonifaci and others $v$ Italian Republic [1991] ECR I-5357. 
stein, decided on 22 December $2010,{ }^{73}$ and Runevič-Vardyn, decided on 12 May $2011 .{ }^{74}$ In both cases, the situation involved a tension between national constitutional identity on the one hand and freedom of movement under Article $21 \mathrm{TFEU}$ and the right to privacy $^{75}$ on the other.

Sayn-Wittgenstein concerned an Austrian-born, German-adopted woman with Austrian citizenship, claiming the right to have her title (Fürstin von Sayn-Wittgenstein), acquired from her adoptive father, entered into the Austrian register of civil status. It was claimed that, as she was an estate agent, the impossibility of using the title of Fürstin would impair her freedom to provide services.

According to the Austrian government, allowing registration of a noble title would be incompatible "with the fundamental values of the Austrian legal order, in particular with the principle of equal treatment enshrined in Article 7 of the Federal Constitutional Law and implemented by the Law on the abolition of the nobility. ${ }^{76}$

While the ECJ recognised that national identity may be taken into consideration in a proportionality analysis, it clarified that reliance on national identity should be treated as a public policy justification ${ }^{77}$ that, in accordance with earlier case law, ${ }^{78}$ has to be interpreted strictly as a 'genuine and sufficiently serious threat to a fundamental interest of society. ${ }^{.79}$

In addition, the ECJ allowed a margin of discretion, in accordance with paragraph 31 of its reasoning in Omega. Finally, in paragraph 93, the ECJ performed the balancing test itself and concluded that Austria acted proportionately in pursuance of a legitimate constitutional aim. The ECJ paid attention to the right to privacy under the Charter and the Convention, but the issue was not discussed further.

Runevič-Vardyn concerned the case of a woman who wanted to have the spelling of her family name amended in her birth and marriage certificates with letters not existing in the Lithuanian alphabet. ${ }^{80}$ The ECJ first

\footnotetext{
73 Case C-208/09 Ilonka Sayn-Wittgenstein v Landeshauptmann von Wien, not yet reported.

${ }^{74}$ Case C-391/09 Malgožata Runevič-Vardyn and Łukasz Paweł Wardyn v Vilniaus miesto savivaldybés administracija and Others, not yet reported.

75 As guaranteed by Article 7 of the Charter of Fundamental Rights of the EU (hereinafter the Charter) and by Article 8 of the European Convention for the Protection of Human Rights and Fundamental Freedoms (hereinafter the Convention).

76 Sayn-Wittgenstein (n 73) para 76.

77 Sayn-Wittgenstein (n 73) paras 83-84.

78 Omega (n 36) para 30; Case C-33/07 Jipa [2008] ECR I-5157, para 23.

79 Sayn-Wittgenstein (n 73) para 86.

80 It follows from paragraph 22 of the judgment that the name 'Malgožata Runevič' was to be changed to 'Małgorzata Runiewicz', and on the marriage certificate from 'Malgožata Runevič-Vardyn' to 'Małgorzata Runiewicz-Wardyn'.
} 
emphasised in paragraph 66 that a 'person's forename and surname are a constituent element of his identity and of his private life', protected both under the Charter and the Convention, and continued by finding that the free movement guarantee under Article 21 TFEU applied to the case.

However, protection of a State's national language, as a part of national identity protected by Article 4(2) TEU, is a value that the European Union must respect (paragraph 86). Accordingly, national identity had to be balanced with both free movement and the right to private life.

With regard to the first point, the tension between the Article 21 TFEU free movement guarantee and Article 4(2) TEU national identity provision, the ECJ followed the Sayn-Wittgenstein argumentation. If it is within the scope of Article 21, a national restriction on the freedom of movement can be justified only subject to a proportionality test. However, unlike in Sayn-Wittgenstein, where the ECJ performed the balancing itseIf, in Runevič-Vardyn the proportionality test was deferred to the national court. $^{81}$

With regard to the second point, the ECJ ruled on the relationship between individual rights and national identity. Again, it is upon the national court to establish whether the national rule leading to the refusal of amending a personal name in a person's relevant documents 'causes serious inconvenience to them and/or their family, at administrative, professional and private levels'. Accordingly, the national court will have to decide whether a fair balance between the interests at issue has been struck. $^{82}$

As can be seen, in both cases, which now appear to be settled case law, the national identity guarantee was interpreted narrowly but remained an element of the balancing analysis. The question remains why, in the former case, the balancing was performed by the ECJ, while it was left to a national court in the latter. One of the obvious reasons lies in the fact that a republican form of government is not a negotiable issue and it would not be reasonable to expect from the national court to set it aside on account of freedom of movement. On the other hand, while language does indeed represent an element of national identity, it is not unthinkable for a national court to allow for exceptions in the case of personal names.

\footnotetext{
81 Runevič-Vardyn (n 74) para 83: 'In the event that the national court finds that the refusal to amend the joint surname of the applicants in the main proceedings constitutes a restriction of Article $21 \mathrm{TFEU}$, it should be noted that, according to settled case-law, a restriction on the freedom of movement of persons can be justified only where it is based on objective considerations and is proportionate to the legitimate objective of the national provisions (see, inter alia, Grunkin and Paul, paragraph 29, and Sayn-Wittgenstein, paragraph 81).' However, in civil law tradition, it is questionable to what extent a national court will be prepared to interpret black-letter law.

82 Runevič-Vardyn (n 74) para 91.
} 
However, when it came to the assessment of a fundamental right against national constitutional identity, the ECJ deferred to the national court.

What appears to have come out of the two mentioned cases is that the ECJ will either recognise national constitutional identity itself or defer the final judgment to a national court.

While in preliminary reference cases the ECJ has a choice either to balance national identity and an EU freedom itself or to defer to a national court, in infraction proceedings there is no such choice. Deference in infraction proceedings would entail leaving the final judgment to national legislative authorities and solving the case in favour of a Member State. However, as we have seen from cases involving Luxembourg official authorities, ${ }^{83}$ the ECJ has preferred to do the job on the grounds of it being the least restrictive alternative. ${ }^{84}$ In both cases, just as in SaynWittgenstein and Runevič-Vardyn, national identity was understood as a legitimate aim which, as an exception to the freedom of movement, had to be interpreted restrictively and subject to a proportionality test.

In addition, it has to be recognised that both the pre-Lisbon Luxembourg cases discussed above dealt with the exercise of official authority, an area of law in which the ECJ insists on a uniform approach. Being an exception from market freedoms, the official authority exception not only has to be interpreted narrowly, but also has to be given 'uniform interpretation and application throughout the Community and cannot therefore be left entirely to the discretion of the Member States. ${ }^{285}$

It would appear that the approach of the ECJ has not changed and still relies on a narrow interpretation of official authority, even in the face of national identity arguments. Preliminary reference cases dealing with the concept of official authority also follow this pattern. ${ }^{86}$ Such a position would appear to confirm Besselink's claim that constitutional identity, though inherently national, is in fact a concept of EU law. ${ }^{87}$ In other words, Article 4(2) TEU has made the discourse about the relationship between EU law and national constitutional law a part of EU constitutional law. While it is easy to agree with Von Bogdandy and Schill that ' $\mathrm{t}]$ here is now a common European discourse on this most sensitive issue', 88

\footnotetext{
83 Commission v Luxembourg (n 61) and Commission v Luxembourg (n 66).

84 Commission v Luxembourg (n 61) para 35; Commission v Luxembourg (n 66) para 124.

85 Case C-405/01 Colegio de Oficiales de la Marina Mercante Española [2003] ECR I-10391, para 38. See also Case 152/73 Giovanni Maria Sotgiu v Deutsche Bundespost [1974] ECR 153, para 5; Case 149/79 Commission v Belgium [1980] ECR 3881, paras 12 and 18.

86 For recent practice, see eg Joined Cases C- C-372/09 and C-373/09 Josep Peñarroja Fa (17 March 2011), not yet reported. For earlier case law see, eg Case C-42/92 Adrianus Thijssen $v$ Controledienst voor de verzekeringen [1993] ECR I-4047.

87 Besselink (n 51) 37.

88 Von Bogdandy and Schill (n 2) 1441.
} 
it is still less clear who, if anyone, has the final say. Or to put it in Paul Feyerabend's terms, the unresolved and possibly unresolvable puzzle lies in the fact that the common European constitutional discourse does not take place in the form of a guided exchange. ${ }^{89}$

Admittedly, the ECJ has no jurisdiction to interpret national law, even less so national constitutional law. ${ }^{90}$ On the other hand, national constitutional courts do not have jurisdiction to interpret Article 4(2) TEU. Besselink suggests a solution according to which national constitutional courts would first determine the substance of national constitutional identity, while the ECJ would determine the meaning of the relevant EU law. Indeed, national identity is primarily ${ }^{91}$ constructed at the national level, not only as a matter of law but also as a matter of common sense. ${ }^{92}$

This does not make national identity absolute. If this were the case, application of the Article 4(2) TEU guarantee could be triggered by a mere claim that a certain value represents a part of national identity, in which case the ECJ would have to exercise self-restraint. In other words, it would provide for the immunity of national law from the application of EU law, which is obviously not the case.

There are only a few hints so far that the ECJ is prepared to defer to national authorities. Most recently, this was the case in Runevič-Vardyn, where the ECJ left it to the national court to balance individual rights against national constitutional identity. An earlier example can be found in UGT-Rioja, which was discussed above. ${ }^{93}$

\footnotetext{
89 According to Feyerabend, guided exchange is a form of communication in which 'some or all participants adopt a well specified tradition and accept only those responses that correspond to its standards.' P Feyerabend, Science in a Free Society (NLB 1978) 29.

90 Feyerabend (n 89) 44.

91 Iris Marion Young has demonstrated how a dominant culture can impose its identity on minority social groups, thus creating a phenomenon of double identity. See IM Young, Justice and Politics of Difference (Princeton University Press 2011). Therefore it does not seem unthinkable that national identity can be constructed by external actors.

92 For the same argument, see C-53/04 Cristiano Marrosu and Gianluca Sardino $v$ Azienda Ospedaliera Ospedale San Martino di Genova e Cliniche Universitarie Convenzionate [2006] ECR I-7213, Opinion of AG Maduro, para 40: 'Doubtless the national authorities, in particular the constitutional courts, should be given the responsibility to define the nature of the specific national features that could justify such a difference in treatment. Those authorities are best placed to define the constitutional identity of the Member States which the European Union has undertaken to respect.' The ECJ, however, ignored the argument.

93 UGT-Rioja (n 57) para 144: 'It is for the national court, which alone has jurisdiction to identify the national law applicable and to interpret it, as well as to apply Community law to the cases before it, to determine whether the Historical Territories and the Autonomous Community of the Basque Country have such autonomy, which, if so, would have the result that the laws adopted within the limits of the areas of competence granted to those infra-State bodies by the Constitution and the other provisions of Spanish law are not of a selective nature within the meaning of the concept of State aid as referred to in Article 87(1) EC.'
} 
This may be a signal indicating the approach of the ECJ in future cases. Namely, apart from national identity cases, the ECJ is in the habit of leaving it to national courts to establish the relevant facts and balance their finding with a relevant national regulatory interest. An example of such practice is well illustrated by Familiapress, ${ }^{94}$ where freedom of the press and press diversity stood in the way of the application of national and EU competition rules. Therefore, Runevič-Vardyn looks rather like a continuance of earlier practice than a venture into a new one.

\subsection{National developments}

As can be seen, the ECJ firmly defends the position that the national identity guarantee under Article 4(2) TEU may not preclude the application of EU law, even in cases of conflict with national constitutional rules. If national identity does prevail, it prevails only because the ECJ has forged the balance in such a way. The same rule, (according to which States may not invoke their constitutional rules in order to justify their failure to comply with a treaty) which is based on the Vienna Convention on the Law of Treaties, holds in infraction proceedings ${ }^{95}$ and preliminary reference cases.

Yet, constitutional identity has become a beloved theme in the legal orders of certain Member States. Interestingly, the battlefield on which the supremacy of EU law over national constitutional rules was challenged took place not on substantive, but on procedural grounds. In this way, the dilemma has been transformed from the question of which rule prevails to that of who decides, or even better, who decides last.

It is probably too simple to ascribe a revival of national constitutional identity awareness to the new wording of the national identity clause in Article I-5 of the Constitutional Treaty and the subsequent entry into force of the Treaty of Lisbon. In fact, the involvement of France, which has recently elevated the national identity idea to the status of a constitutional principle, was modest at the time when the provision was discussed within the European Convention. As can be seen from the documents of the Secretariat of the European Convention, ${ }^{96}$ the proposed amendments to the then definition of national identity included that "national identity

\footnotetext{
94 Case C-368/95 Vereinigte Familiapress Zeitungsverlags- und vertriebs GmbH $v$ Heinrich Bauer Verlag [1997] ECR I-03689.

${ }^{95 \mathrm{~F}}$ or a good example of how a national constitution may not justify non-implementation of a directive, see Case C-323/97 Commission v Belgium [1998] ECR I-4281, para 8: The Court has consistently held that a Member State may not plead provisions, practices or circumstances existing in its internal legal system in order to justify a failure to comply with the obligations and time-limits laid down in a directive (see, in particular, Case C-107/96 Commission v Spain [1997] ECR I-3193, para 10).'

96 Reactions to draft Articles 1 to 16 of the Constitutional Treaty - Analysis, CONV 574/1/03 REV 1, Brussels 26 February 2003 (04.03).
} 
comprises, as appropriate, the Constitutional "structures" / organisation of public authorities at local and regional level/selection of languages/local autonomy/status of churches.' However, French input was negligible. ${ }^{97}$

Michel Troper suggests that French constitutional doctrine was directly triggered by the concept of constitutional identity, as introduced by the Constitutional Treaty and later on embraced by the Treaty of Lisbon. ${ }^{98}$ It would appear that the French constitutional reform of 1 March 2010 was motivated by an intention to insulate the French constitution against European law having the last say. ${ }^{99}$ Again, Troper puts it succinctly. Since EU law prevails over national constitutional law, 'a French court wishing to avoid acknowledging the supremacy of European law must use another argument than the fact that some principle of French law is a constitutional norm. This is where "constitutional identity" comes into play.'100

The doctrine was also embraced by the Conseil Constitutionnel, which in 2006 adopted a position according to which 'transposition of a directive may not run counter to a rule or principle inherent to the constitutional identity of France, except when the constituting power consents thereto.'101

In order to avoid repeating the emerging literature on the point, ${ }^{102}$ suffice it to say that the main effects of the French constitutional reform

97 According to the Summary provided by the Secretariat, the amendments were introduced by "Mr Michel +5 Belgian members of the Convention + observers + Lopes + Hubner + Einem + Kiljunen + Vanhanen + Cushnahan + Olesky + Tiilikainen + Peltomäki + Costa + 3 Portuguese + Santer +2 Luxembourgers + Lequiller + Frendo + Bonde +8 members of the Convention + Wittbrodt + Fogler + Brok + 12 EPP members of the Convention + Katiforis + Serracino-Inglott (+ Inguanez) + Chabert (observer) + 5 members of the Convention (observers)'.

98 M Troper, 'Sovereignty and Laïcité', 30 Cardozo L Rev 6 (2009) 2561, 2573. This is also confirmed by Josso, who writes that before the Constitutional Council's decision, there were no other statements of any specific elements of national constitutional identity; S Josso, 'Le caractère social de la République, principe inhérent à l'identité constitutionnelle de la France', report to the Paris Congress of Association française de droit constitutionnel, 5. See <http://www.droitconstitutionnel.org/congresParis/comC1/JossoTXT.pdf> accessed 14 August 2011.

99 See B Kostadinov, 'Prethodna pitanja ustavnosti u nacionalno pravu i pravo EU' in T Ćapeta, I Goldner Lang and S Rodin (eds), Prethodni postupak u pravu Europske unije (Narodne novine 2011). Kostadinov refers to V Bernaud and M Fatin-Rouge Stéfanini, 'La réforme du contrôle de constitutionnalité une nouvelle fois en question? Réflexion autour des articles 61-1 et 62 de la Constitution proposé par le comité Balladur', Revue francaise de Droit constitutionel, no hors-série (2008) 190.

100 Troper (n 98) 2572.

101 Constitutional Council decision no 2006-540DC, July 27, 2006, JO '[L]a transposition d'une directive ne saurait aller à l'encontre d'une règle ou d'un principe inhérent à l'identité constitutionnelle de la France, sauf à ce que le constituant y ait consenti.' In such a case, it would be the national law implementing the directive that would be held unconstitutional. 102 See F Fabbrini, 'Kelsen in Paris: France's Constitutional Reform and the Introduction of A Posteriori Constitutional Review of Legislation', German Law Journal, vol 09 no 10 (2008) 1297; S Rodin, 'Back to Square One: The Past, the Present and the Future of the Simmenthal Mandate', in Beneyto and Pernice (eds) Constitutional Challenges in the Light of the Recent Case Law of National Constitutional Courts (Nomos 2011). 
and, in particular, the newly established abstract constitutional review and 'priority preliminary reference' to the Constitutional Council, run against the well-established supremacy law of the ECJ. First, if a law is declared unconstitutional by the Conseil Constitutionnel as being contrary to EU law, the power of an ordinary court judge to disapply it is pre-empted. Second, an ordinary judge is instructed not to address a preliminary reference to the EJC before the Conseil Constitutionnel has spoken on the matter.

The answer of the ECJ came in Melki and Abdeli, ${ }^{103}$ and not surprisingly follows the existing case law. The ECJ took the effort to explain in great detail what requirements a national interlocutory constitutional review has to meet in order to be compatible with EU law. As the ECJ clarified in paragraph 57 of the judgment, Article $267 \mathrm{TFEU}$ precludes national legislation establishing an interlocutory constitutional review, insofar as the procedure prevents 'all the other national courts or tribunals from exercising their right or fulfilling their obligation to refer questions to the Court of Justice for a preliminary ruling.'

In this way, the ECJ maintained the judicial dialogue with ordinary courts, and rendered the legal opinions of the Conseil Constitutionnel adopted in interlocutory constitutional review procedures irrelevant from the perspective of the supremacy of EU law. ${ }^{104}$

The main problem of the French approach to constitutional identity is that it sweeps too broadly and fails to provide for its protected core.

Germany has a long record of dialogue with the ECJ. The German Federal Constitutional Court (BVerfG) triggered the evolution of the protection of fundamental rights in the EU by insisting on standards of protection substantially comparable to those under the Basic Law.

However, so far, the BVerfG has never addressed a preliminary reference to the ECJ. Instead, its influence has always been exerted through its position as the 'court of last say' in the European judicial dialogue. Namely, even after the ECJ has spoken on a matter of EU law, the BVerfG is still in a position to pass judgment on issues of national constitutional law, and in that way protect national constitutional identity.

\footnotetext{
103 Joined Cases C-188/10 and C-189/10, Aziz Melki and Sélim Abdeli (n 37). For a more detailed discussion see Rodin (n 102).

${ }^{104}$ It should be noted that the judgment in Melki and Abdeli, similar to the judgment in Elchinov, supports the Rheinmühlen case law, according to which a referring court is not bound by the legal interpretation of the national appelate court. This is an important procedural element of the supremacy of EU law. See 146/73 Rheinmühlen-Düsseldorf [1974] ECR 139. The same follows from C-210/06 Cartesio Oktató és Szolgáltató bt [2008] ECR I-09641, paras 93-98.
} 
In 1992, in its decision in the Maastricht case, ${ }^{105}$ the BVerfG resorted to two powerful devices: the essential contents guarantee, under which the BVerfG acts as guardian of the core of fundamental rights under Article 19(2), which are also protected by the constitutional eternity clause under Article 79(3) of the Basic Law, and the ultra vires doctrine, according to which it can review and refuse to apply acts of the Union which exceed the transferred powers. ${ }^{106}$ According to the BVerfG in $\mathrm{Li}$ sbon (inferring from the Maastricht judgment), constitutional identity is guaranteed by Article 79(3) of the Basic Law, and the constituent power has not granted the representatives and bodies of the people a mandate to dispose of the identity of the constitution.' ${ }^{107}$ As the BVerfG clarified:

The obligation under European law to respect the constituent power of the Member States as the masters of the Treaties corresponds to the non-transferable identity of the constitution (Article 79.3 of the Basic Law), which is not open to integration in this respect. Within the boundaries of its competences, the Federal Constitutional Court must review, where necessary, whether these principles are adhered to. ${ }^{108}$

Accordingly, any act of the Union which would impinge on national constitutional identity would be ultra vires and thus inapplicable in Germany, ${ }^{109}$ and it is for the BVerfG to refuse to apply it. ${ }^{110}$

In July 2010, the BVerfG significantly narrowed the ultra vires doctrine in the Honeywell judgment, ${ }^{111}$ where it held that before an act of the EU can be scrutinised on ultra vires grounds, the ECJ should be given an opportunity to rule on the matter, either in an annulment action or as a matter of preliminary reference. When it comes to a constitutional review, the BVerfG can declare an act of the EU ultra vires. However:

the act of the authority of the European Union must be manifestly in violation of competences and ... the impugned act is highly significant in the structure of competences between the Member States and the Union with regard to the principle of conferral and to the binding nature of the statute under the rule of law. ${ }^{112}$

\footnotetext{
105 BVerfGE 89, 155.

106 The BVerfG applied this doctrine in BVerfGE 58, 1 (30-31); 75, 223 (235, 242); 89, 155 (188), and notably in the Lisbon judgment, BVerfG, 2 BvE 2/08 of 30.6.2009. See M Mahlmann, 'The Politics of Constitutional Identity and its Legal Frame: The Ultra Vires Decision of the German Federal Constitutional Court', 12 German LJ, 11 (2010) 1407.

107 Lisbon (n 106) para 218.

108 Lisbon (n 106) para 235.

109 Lisbon (n 106) para 241.

110 Lisbon (n 106) para 240.

111 BVerfG, 2 BvR 2661/06 of 6.7.2010. See C Möllers, 'Constitutional Ultra Vires Review of European Acts only under Exceptional Circumstances; Decision of 6 July 2010, 2 BvR 2661/06, Honeywell', 7 Eur Const L Rev (2011) 161.

112 Honeywell (n 111) paras 60 and 61.
} 
While the BVerfG has never addressed a preliminary reference to the ECJ, paragraph 60 of the Honeywell decision indicates that it is prepared to do so. No less importantly, a national court is under a constitutional obligation to refer to the ECJ, and failure to do so may lead to a violation of the constitutional right to a lawful judge under Article 101(1) of the Basic Law. ${ }^{113}$

In short, the BVerfG has linked German constitutional identity to the eternal and entrenched status of fundamental rights and the core of their protection under Article 79(3) of the Constitution. By doing so, it has ensured it has the last say in cases involving fundamental rights but, at the same time, it has allowed enough space for the ECJ to rule on the interpretation and validity of EU law. Importantly, the BVerfG has wrapped its doctrine in the principle of sincere co-operation under Article 4(3) TEU and maintained its doctrine of co-operation between the two courts and also a doctrine of friendliness to EU law. ${ }^{114}$ Being fully aware of the ECJ's position, according to which national identity can justify a departure from market freedoms only if it cannot be safeguarded in any other way, ${ }^{115}$ the BVerfG has reserved its position as protector of national constitutional identity for situations in which fundamental political structures 'cannot be safeguarded in any other way'. ${ }^{116}$

\section{Conclusion}

The identities of the Member States are older than the Founding Treaties and exist separate from and regardless of EU law. Moreover, just as individual or group identities continue to exist in different settings of governance, the national identities of the Member States will continue to exist regardless of what form or substance the EU takes in the future. In this sense, Article 4(2) TEU reiterates the truism that national identities do exist. Having said that, it begs an answer to the question of what the legal consequence is of such a recognised existence of national identities.

The Treaty of Lisbon has not significantly affected the national identity jurisprudence of the ECJ. Even before its entry into force on 1 December 2009, the ECJ had developed a main interpretative strategy how to address Member States' constitutional claims. As I have demonstrated above, the pre-Lisbon case law can be grouped into three evolutionary phases. As a result, the ECJ developed its doctrine of margin of discretion, implied and explicit, and made it clear that national identity cannot be absolute. The ECJ also made a distinction between claims that can be

\footnotetext{
${ }^{113}$ Honeywell (n 111) paras 88-90.

${ }^{114}$ Lisbon (n 106) para 240.

115 Commission v Luxembourg (n 61) para 35; Commission v Luxembourg (n 66) para 124.

${ }^{116}$ Lisbon (n 106) para 240.
} 
called national identity small, which are treated like ordinary public policy justification, and claims which can be called national identity large, which trigger some kind of deference to national judicial or regulatory authorities. Accordingly, a viable national identity claim makes a regulatory aim legitimate per se, which in national identity small cases results in the application of the least restrictive alternative test, and in national identity large cases leads to deference.

The Treaty of Lisbon has added more clarity to the concept of national identity. As far as the Treaties are concerned, the Treaty of Lisbon was the first one to make clear that national identity refers to national constitutional and political structures. In a way, Lisbon accommodated national claims to the Vienna Convention rule that States may not claim an internal law in order to justify a violation of a treaty.

The situation is quite different if a treaty itself allows some discretion to the States, and this is exactly what Article 4(2) TEU did. However, the question remains: what counts as a viable national identity claim? Is national constitutional identity, as Besselink puts it, a concept of EU law, or is there a plurality of national concepts which have to be respected as a matter of law? A plausible first-hand answer would be that a viable national constitutional identity claim has to rely on an entrenched constitutional rule, value or fundamental choice. It must not be a mere policy choice, or grant of jurisdiction to local authorities, but has to be essential for the recognition of a national constitutional order, and differentiated from other constitutional orders.

The post-Lisbon era has brought about developments at both the European and national level. While the Treaty has not significantly affected the approach of the ECJ described above, France and Germany have started to increasingly rely on constitutional identity, challenging the claim that it is an exclusive concept of EU law.

In national identity small cases, the ECJ has maintained its public policy approach, combined with the least restrictive alternative test. Under this approach, national identity cannot justify restriction of market freedoms if there is an alternative, less restrictive, way to protect national identity. This is well illustrated by the Commission v Luxembourg cases, which although decided in different stages of European integration, follow the same pattern of analysis.

The situation is different in national identity large cases, where the ECJ has shown a readiness either to recognise a national identity claim out of hand (Sayn-Wittgenstein) or defer to the national court (RunevičVardyn). What qualified the two last mentioned cases as national identity large cases? In the first case, it appeared to be a fundamental constitutional choice of a republican form of government. In the latter case, it was 
the recognition of the ECJ that a national court is better equipped to do the balancing test in a sensitive language case. This approach, however, is not prompted by the Lisbon Treaty, but follows the same line of reasoning and deference which the ECJ adopted in UGT-Rioja back in 2008. ${ }^{117}$ Arguably, as early as 2008, the same provision was already present in the aborted Constitutional Treaty and was an anticipated part of the incoming Treaty of Lisbon. However, it remains unclear whether deference to the national court is motivated by the wish to defer a value choice or by a more practical reason, that is, to allow a national court to establish the relevant facts, as the ECJ did, for example, in Familiapress.

Another tendency that can be seen in cases decided by the ECJ is that it will be less ready to concede a national identity claim in cases where there is a well-established interpretation and a need for uniform interpretation of EU law. ${ }^{118}$

More substantive developments have taken place on the side of the Member States, notably in France and Germany. France implemented a constitutional reform that resulted in a Kelsen-like system of interlocutory constitutional review. The new mechanism was introduced in an attempt to give the Conseil Constitutionnel a voice at the European level and possibly pre-empt conflicts between French and EU law before they reached the ECJ in the form of a preliminary reference. However, by focusing on a procedural instrument of interlocutory constitutional review, the newly introduced system not only set a collision course with the well-established preliminary reference case law of the ECJ, ${ }^{119}$ but also fell short of defining the substantive core of a French constitutional identity that could serve as a countervailing force in Article 4(2) TEU cases.

The German approach appears to be more sober. It is based on the principle of co-operation and a clearly defined constitutional identity core. The relationship with EU law is understood as one of co-operation, and the role of the BVerfG is a complementary and subsidiary one. National constitutional identity is asserted, but dormant, allowing the BVerfG the final say in critical cases, but not interfering in national identity small situations.

Article 4(2) TEU has arguably created the potential for a new balance between national identity and market freedoms, and Article 4(3) TEU has re-defined the duty of loyal (or sincere) co-operation. Under the new provision, the obligation of sincere co-operation has become reciprocal,

\footnotetext{
117 UGT-Rioja (n 57).

118 Colegio de Oficiales de la Marina Mercante Española Supra (n 85), and the case law cited therein.

${ }^{119}$ Rheinmühlen-Düsseldorf (n 104); more recently, see Cartesio Oktató és Szolgáltató bt (n 104) paras 93-98.
} 
and it is for the Union and Member States to assist each other in the performance of the Treaties.

In the context of Article 4(2) TEU, this can mean that Member States are at liberty to define the core of national constitutional identity, while the ECJ retains the power to interpret the broader normative framework within which national identity operates in the EU. Too extensive an interpretation of the national identity clause has the potential to block or even reverse the course of European integration. On the other hand, too narrow an interpretation would render Article 4(2) devoid of its useful effect.

The role of Article 4(2) TEU is twofold. As a competence rule, it imposes limits on EU regulation, even in cases where such regulation would otherwise be permissible. As an interpretative rule, it provides guidance for the ECJ and national courts on how to interpret the relationship between EU and national law.

As the law appears to stand today, the Member States are under an obligation under Article 2 TEU not to construe national identity in a way that is in confrontation with the fundamental rules, principles and values of the EU. On the other hand, the ECJ, within the limits of its jurisdiction, determines to what extent the Treaties are to be interpreted as allowing a margin of discretion in national identity claims, or as treating such claims as an ordinary public policy justification. Certainly, national constitutional courts retain the right to rule on the application of national constitutional law even after the ECJ has spoken, and this can lead to a collision between national constitutional and EU law. However, we have not witnessed such a development yet. 